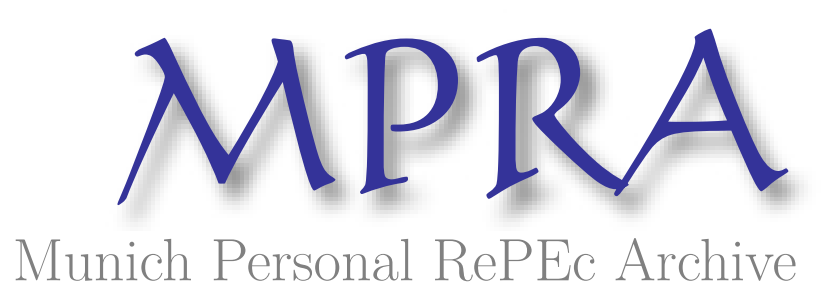

\title{
Intergenerational Cultural Programs for Older People in Long-term Care Institutions: Latvian Case
}

Rasnača, Liga and Rezgale-Straidoma, Endija

2017

Online at https://mpra.ub. uni-muenchen.de/84649/

MPRA Paper No. 84649, posted 05 Mar 2018 14:41 UTC 
Suggested Citation: Rasnača, L., \& Rezgale-Straidoma, E. (2017).

Intergenerational Cultural Programs for Older People in Long-term Care

Institutions: Latvian Case. In Ł. Tomczyk \& A. Klimczuk (Eds.), Selected

Contemporary Challenges of Ageing Policy (189-219). Kraków: Uniwersytet

Pedagogiczny w Krakowie. Doi: 10.24917/9788380840911.9

\title{
LĪGA RASNAČA ${ }^{1}$
}

\section{ENDIJA REZGALE-STRAIDOMA ${ }^{2}$}

\section{Intergenerational Cultural Programs for Older People in Long-term Care Institutions: Latvian Case}

\begin{abstract}
An ageing population is a global phenomenon that takes place in Latvia, too. The active ageing policy is a social response to social challenges caused by demographic changes. Growing generational gap is a challenge to all "greying societies" in Europe and Latvia in particular. The active ageing policy is oriented to provide possibilities for older adults to live independently. However, long-term care institutions (LTCIs) remain necessary, especially for those who live alone and have serious health problems. LTCIs are mostly orientated to provide primary needs and health care. People regardless of their age also need a social and cultural life, but for older people who live in LTCIs, it is insufficient. The study shows those who are residing in LTCIs settings are subject to everyday routine. LTCIs care provision is very much dependent on the authorities of the institution. The insufficient level of interaction between older people and the more active part of society prevents the finding of effective ways of achieving that the care in LTCIs is in accordance with the active

\footnotetext{
${ }^{1}$ Līga Rasnača, University of Latvia, liga.rasnaca@lu.lv.

${ }^{2}$ Endija Rezgale-Straidoma, University of Latvia, endiarezgale@gmail.com.
} 
ageing policy. The study aims to find out ways how intergenerational cultural programs of professional and amateur activities are implemented in LTCIs. The study uses a qualitative approach to explore how LTCIs intergenerational cultural programs are helping to keep our youngest and oldest generations connected.

Key words: Intergenerational Solidarity, Cultural Programs, Active Ageing, Long-Term Care Institution, Generational Gap

\section{Introduction}

The ageing population is a global phenomenon of the twenty-first century, and rapid science and technology developments are one of the consequences among others. People are capable of living longer lives due to "medical discoveries, new surgical technologies and decline in infant mortality and advanced treatment mode for previously fatal diseases" (Miller, 2002, p. 4.). "The number of people aged 65 or older is projected to grow from an estimated 524 million in 2010 to nearly 1.5 billion in 2050, with most of the increase in developing countries" (WHO, 2011). The rapidly ageing population is a challenge for both global and local policy makers. The long-term care and health care for older people have become a burning issue as never in the whole world, and Latvia is not an exception. The Organization for Economic Co-operation and Development (OECD) reports that population ageing will have an impact on government budgets. The overall prognosis is that by 2050 , it expects to exceed one-fifth of national income in most of the OECD countries (OECD, 2011).

According to the World Health Organization (WHO) strategy, one can conclude that rapidly ageing population is contributing to increasing demand for social care services (WHO, 2016) and bringing new challenges in long-term care for older people. Latvia also is one of the European countries whose population consists of almost one-fifth of older people. The proportion of older people in Latvia has increased since regaining the independence in 1991 (CSB, 2016). The old-age population in 2013 (population aged 65 or over) in Latvia was $18.9 \%$ with a tendency to increase by 2030 up to $25.5 \%$ (European Commission, 
2015, p. 342). The increasing size of older people results in the growth in public expenditure in this group. It forces policy makers to find new solutions that relate to issues considering the enhancement of life satisfaction for older adults (Toepoe, 2011). Similar problems are in Latvia, too and the biggest challenge for policy makers is how to make the more satisfactory living in LTCIs for older people. "Alienation in communication and mutual lack of knowledge exchange between the generations reduce the chances for satisfactory mutual relations between the younger and older family members" (Republic of Slovenia Ministry of Labour, Family, and Social Affairs, 2010). Rapidly ageing population brings in new challenges on how to establish new relations between family, community, and residential institutions. It explains the increased need for financial resources in care for older adults and changes in the nature of it (Macionis \& Plummer, 2008) by calling "for a holistic approach based on a shared vision of a society inclusive of all ages" (AGE Platform Europe, 2010).

People regardless of their age also need a social and cultural life, but for older people who live in LTCIs, it is very limited. There are a wide variety of intergenerational programs that promote a healthy and active ageing for older adults in their communities in Latvia, but the coverage and availability of programs are limited due to lack of financial support, human resources, and appropriate infrastructure in municipalities. Most of the time the initiators and organizers of these programs are nongovernmental organizations (NGOs), churches, schools, and various interest clubs for example interest clubs for older adults. The active ageing policy is oriented to provide possibilities for older people to live independently. LTCIs are mostly orientated to provide primary needs and health care. Helen Featherstone (2014), the Senior Manager at Arts Council England, emphasizes that the arts can be used in an efficient manner to deal with many issues encountered by older adults, for example with the most common among older people such as loneliness. Most of the cultural programs are supervized by aged care services. There is an insufficiency of systematized information on how art and culture are used for intergenerational solidarity programs. 
The study presented in this chapter aims to find out ways how intergenerational cultural programs of professional and amateur activities are implemented in LTCIs. Authors particularly are interested in what kind of cultural programs are implemented in LTCIs to provide healthy and active ageing for older adults considering the fact they are living in institutionalized settings. What kind of particularities can be identified in institutionalized settings to make it possible for intergenerational cultural programs to happen? Research tasks are: to analyze main concepts, political documents, and realization of intergenerational cultural programs, to describe research method, to analyze findings and to start a discussion.

The study is based on five research questions. These are: (1) How intergenerational cultural programs for older people in LTCIs are organized? (2) What is the spatial layout of the place where intergenerational cultural programs are held? (3) How are the intergenerational cultural programs happening? (4) Who undertook an initiative to organize intergenerational cultural programs? (5) Who are the participants of intergenerational cultural programs?

Authors are using a qualitative approach to explore how LTCIs intergenerational cultural programs are helping to keep our youngest and oldest generations connected. The study consists of a theoretical framework that supports the research, methods of data collection, description of the situation of organizational and financial framework concerning cultural programs for older people in LTCIs, analysis of interview results, discussion and conclusions on main findings are drawn in the final part of the article.

\section{Theoretical Framework}

To support this study in this section authors are describing main concepts: intergenerational solidarity, generational gap, active ageing, long-term care institutions (LTCIs) and cultural programs.

Intergenerational solidarity means a social cohesion between generations and active ageing encouraging older people to be active in society and motivate them to healthy ageing (OECD, 2011). The European Union (EU) is aware of the importance of intergenerational solidarity. The European Day of 
Solidarity between Generations in 2012 (EY 2012), was an excellent opportunity to make many visible initiatives across the EU and "remind of the need for greater solidarity and cooperation between age groups in our ageing societies" (WeDO, 2012). Intergenerational solidarity means intentional interaction between two or more persons of different ages (Amparo Cruz-Saco, 2010). It encourages for both young and old to gain new knowledge, to develop new skills, exchange experiences. That can be achieved by promoting volunteer approach by motivating people of different generations to live, work and attend various cultural events together (Latvijas Republikas Labklājības Ministrija, 2012). The authors are acknowledging that the intergenerational solidarity is a necessity for the cohesion of every community living in greying societies.

To stabilize intergenerational solidarity, it is also important the renegotiation of the balance between continuity and innovation over time through the succession of one generation by another. Solidarity between generations is best understood within the context of shared expectations and obligations regarding the ageing of individuals and the succession of generations (Bengtson \& Oyama, 2007). Intergenerational solidarity is more often experienced within a family of an older adult, then with nonbiologically linked society members from different generations. However, there is a need for mobility and involvement of all society members in all age groups. The primary challenge of this new paradigm, called intergenerational solidarity, is how to create connections among non-biologically linked older and younger people that could promote the social growth, learning and emotional stability that often characterizes relationships between older and younger family members (Newman \& Hatton-Yeo, 2008).

"Intergenerational programs refer to activities or programs that increase cooperation, interaction or exchange between any of two generations." Since the late 1970s has been growing interest in intergenerational programs and they are not one type of planned actions any longer (Kaplan \& Sanchez, 2014). OECD acknowledges intergenerational solidarity "as a desirable value in itself." Intergenerational solidarity is achieved when generations 
are respecting each other's views and can compromise between each other on the way forward (OECD, 2011). It also means bonding between generations and it can be achieved by reflecting "personal wishes and material goals, emotional bonds, and rational justifications, altruism and self-interest, caregiving, and care to receive" (Amparo Cruz-Saco, 2010). However, fast-paced lifestyle is making this connection between young and old recently less common. That can lead both young and old to social isolation and miss opportunities to learn from one another (BC Care Providers Association, 2009). The problem that occurs within organizing intergenerational programs is difficult to develop high-quality intergenerational activities (Generations United, 2006). Intergenerational programs are not only playing an important role in society by bringing generations together but also provide active ageing for older adults.

The intentional interaction between generations helps to build intergenerational relationships. This matter was called to attention in the 1960s when for the first time was addressed the conflict between generations, and it was called the "generation gap" (Bengtson \& Achenbaum, 1993). It is an inevitable barrier for the communications between the young and the old ones. In the late 1970s, intergenerational programs were included in social planning models whose purposes were to connect older and younger people in formal settings (Newman \& Hatton-Yeo, 2008). They are playing an important role in recognizing our basic human need to connect with others (BC Care Providers Association, 2009). One of the main reasons for these programs is to bridge the perceived generation gap between the young and the old but who are young at their heart (Davidson \& Boals-Gilbert, 2010). Intergenerational programs are built on beneficial activities for both generations. The designed activities are for achieving specified program goals that each participant can benefit from.

Generational gap (in some literature it is also called generation gap) is a concept used to point out diversity between younger and older generations regarding cultural norms (Mather, 2007). The meaning of generational gap mostly stands for an inevitable barrier for the communications between the younger and the older generations. The reason for this conflict to become 
visible as consequences of urbanization, industrialization, and family mobility (Bengtson \& Achenbaum, 1993). In the 1960s scholars used this concept to find an explanation and describe differences in culture between parents and their children. The cultural differences mainly identified in cultural tastes in music, fashion, and technology among these two generations (Mather, 2007). Since that time has been implemented various programs and initiatives to bring all generations closer together.

The active ageing policy is a social response to social challenges caused by demographic changes. The WHO defines "active ageing as a process of optimizing opportunities for health, participation, and security in order to enhance the quality of life as people age. It applies to both individuals and population groups" (WHO, 2002). The Third Age is a new concept introduced within the policy of active ageing. It stands for the idea of activity in the post-retirement years. "The Third Age is characterized as a time of growth and personal development when individuals would have both the resources and the energy to give to new activities and learning" (Lloyd, Tanner, Milne, Mo Ray, Richards, Sullivan, Beech, \& Phillips, 2014). Active ageing one also can understand as a healthy, successful, positive, or productive ageing.

The fact that long-term care services are fragmented (private and public; local and centralized) could face a difficulty to materialize the policy of an active ageing in LTCIs. With an ageing population, early retirement options sometimes can be limited, and active ageing policy encourages older employees to remain in the labor force longer (The World Bank, 2015). Active and healthy ageing is crucial not only for active older adults living independently but also for those older adults who reside in LTCIs (Rezgale-Straidoma \& Rasnača, 2015; Rezgale-Straidoma \& Rasnača, 2016). The active ageing policy stands for providing more flexible work arrangements, including increased part-time employment both for workers transitioning to retirement and care providers.

Long-term care institutions (LTCIs) are "social institutions which provide a person who cannot take care of himself or herself due to old age or state of health, as well as orphans and children, left without a parental care with housing, 
full care and rehabilitation" (Latvijas Republikas Saeima, 2002). The authors are interested in LTCIs for older people, but general meaning and purpose of LTCIs can be applied to all social groups mentioned in the definition above. Generally, in LTCIs are admitted people whose safety and wellbeing is at risk due to their inability to take care of themselves (Alders, Comijs, \& Deeg, 2016). LTCIs put not only a financial strain on society but also challenges authorities on how to provide the appropriate health and social care, housing, and suitable environment for older adults so that they could maintain the quality of life as high as possible. Historically long-term care has always been one of the biggest issues to human life course. It is only quite recently that long-term care is addressed as a specific social risk, requiring the intervention of the welfare policy (Österle \& Rothgang, 2010). Several stakeholders, the central and local government, NGOs, and private organizations, are involved in the provision of longterm social care for older people.

Cultural programs can consist of a wide variety of art programs. The cultural programs are one of the forms of creative capital including creativity, originality, and artistic value. "Creative capital of older people must be understood as their activities and their work, that could be an opportunity for maintaining a healthy lifestyle ... and enjoying a high quality of life" (Klimczuk, 2015, pp. 26-31). They range from painting, writing, poetry, jewelry making, and material culture, to music (Cohen, Perlstein, Chapline, Kelly, Firth, \& Simmens, 2006). Music as a cultural program can include older people singing in the choir or the ensemble. Very often LTCIs in cultural or art programs call "activity" because of its format, which is a brief and time-bound event. LTCIs have a lot to choose from on how to introduce arts experiences to its residents. One way is to bring in the arts to LTCIs, for example inviting artists to perform at LTCIs. Another option for providing cultural activities for older people in LTCIs could be to have an artist or artists as a staff member who can come up with own ideas for various art and culture activities. Some LTCIs are combining both options to provide older people with cultural life (Rollins, 2013). All cultural programs are based on participation and interpersonal interaction of older people with 
others. That requires social engagement, too (Cohen et al., 2006). They are social tools that offer at least two generations the opportunities to interact with each other and to be active participants in the community (Generations United, 2007). The intergenerational cultural programs for older people in LTCIs play an important part in bridging the generational gap.

Theory of institutional ecology can use to analyze intergenerational cultural programs in LTCIs. The theory focuses on special layout and social space, which is occupied by the organizational institution or process (Abrutyn, 2012; Piszcek, 2014). It is very important for the intergenerational cultural programs provided by different actors (state, local government, and private organizations) and various spatial layouts in LTCIs.

\section{Data and Methods}

The study design is case study focusing on the organizational framework of intergenerational cultural programs in the state, local government and private LTCIs for older people. The research methods are documented analysis and semi-structured interviews.

Documents governing the social welfare system in Latvia were reviewed and analyzed: EY 2012, the Law on Social Services and Social Assistance which lays down the principles of providing social services and the range of people eligible to receive such services, Regulations on state and local government social care institutions, the Convention on the Rights of Persons with Disabilities and several examples of intergenerational cultural programs for older adults in Latvia provided by NGOs and local governments.

Data were collected by conducting ten semi-structured interviews with cultural event managers in LTCIs and both professional and amateur artists. Interviews included main questions that helped to get the answers to the research questions:

- What is the way, how organizing intergenerational cultural programs for older people in LTCIs?

- What is the spatial layout of the place where intergenerational cultural programs are held? 
- How are the intergenerational cultural programs happening?

- Who undertook initiative to organize intergenerational cultural programs?

- Who are the participants of intergenerational cultural programs?

Interviews were done in May and June of 2016 during the visits to LTCIs and taking part in some intergenerational cultural programs. Interviews were done in all three available kinds of LTCIs in Latvia- state, local government and private. The LTCIs chose based on authors' personal network. Authors of study visited five LTCIs: two private institutions "Upe" and "Vilnis" in a rural area, two institutions of local government "Ezers" and "Koki," and one state institution "Krasts." Due to very sensitive issue and the fact that there are not so many LTCIs in Latvia, the real names of LTCIs in this study are changed.

The subject of interviews is involved with the financial matter, and that makes it a susceptible issue. Interviewed respondents preferred to remain anonymous and ask for guarantees of confidentiality, describing it as self-protection in the professional and administrative environment. Five cultural event managers in all five LTCIs were interviewed while only two of them were staff members ("Krasts" and "Ezers").

Their work obligation is to take care of cultural life for older people. That includes organizing intergenerational cultural programs by inviting various artists and including older people in a variety of art and musical activities (e.g., workshops, concerts, and trips to museums). The cultural event manager from "Krasts" in the past worked a lot with artists and still currently works as the master of ceremonies on weekends, and that is helping a lot to find volunteers to participate in intergenerational cultural programs in "Krasts." The cultural event manager from "Ezers" previously was a musician that is why he is enjoying his current job very much. The cultural event managers who were interviewed in the second institution of local government "Koki" was a social rehabilitator by occupation in this institution but started to work with older adults as volunteer ten years ago. Based on his enthusiasm and 
care for older people he very actively participates in organizing cultural life in "Koki."

In the private LTCIs, the cultural event manager portrait slightly differs. In "Upe" the cultural event manager was the owner of this institution and takes an active participation in organizing cultural events and intergenerational programs for older people using his personal contacts with various artists and organizations. The last expert of LTCI "Vilnis," who previously worked as a teacher, admits that loves his current job. At the same time, semi-structured interviews were done with an artist who participated in intergenerational cultural programs on that day in LTCI. The artists who were interviewed were professional pianists, singers, and actors. They also wanted to stay anonymous in this study.

\section{Organizational and Financial Framework Concerning Cultural Programs for Older People in LTCIs}

LTCIs in Latvia are still the most important way to take care of older people in comparison to other EU countries. According to gathered data by Ministry of Welfare of the Republic of Latvia on average, $83 \%$ of people who are in need for social services receive them in institutions. Only $17 \%$ receive social services through other alternative ways (Latvijas Republikas Labklājības Ministrija, 2013). Older people draw up the largest number of people who need to be institutionalized. The Central Statistical Bureau of Latvia (CSB) reports that 567448 people are older adults out of 1.978 million of the total population in Latvia (CSB, 2015). The older population is considered aged 65 and older but in this study authors referring to older people who reside in LTCIs in Latvia. They are not necessarily all above the age of 65 because retirement age used to be 62 years and it is increasing every year in Latvia, authors are considering the fact that majority of older people residing in LTCIs are people who reached their retirement age but some of them can be under age of 65 . Recipients of old age pensions at the end of the year 2015 are 466700 (CSB, 2015). About 137000 older people in Latvia are in need of social care. The reality is that only 10000 older people receive LTCIs and 11 600 receive care at home (Bērziņš, 2015). 
Long-term care for the many of older people is one of the major solutions where to spend their last days of life in current Latvian situation. In order to improve services for older people, it requires considering each component of care because many older adults are using multiple services (Oliver, Foot, \& Humphries, 2014). Intergenerational cultural programs must be one of the elements to make lives satisfactory for older people in LTCIs. The year of 2012 was European Year for Active Ageing, and Solidarity between Generations (Tymowski, 2015). Latvia also took part in this initiative by organizing various intergenerational cultural programs in LTCIs (Latvijas Republikas Labklājības Ministrija, 2011). However, after the year 2012 to some activities continuity did not follow. The Convention on the Rights of Persons with Disabilities Article 30 "Participation in cultural life, recreation, leisure and sport" states that "States Parties recognize the right of persons with disabilities to take part on an equal basis with others in cultural life, and shall take all appropriate measures to ensure that persons with disability are entitled to participate in cultural activities" (United Nations, 2006). Latvia signed this resolution in 2008 (Latvijas Republikas Saeima, 2010). Since there are many older people with a disability, then this article in Convention authors apply to older adults, too. However, in Latvian Law on Social Services and Social Assistance (Latvijas Republikas Saeima, 2002) one cannot find an article where would be mentioned that older people in LTCIs must be provided with cultural programs. That explains why LTCIs do not have financial funds for cultural intergenerational cultural programs and currently are purely dependent on volunteers or some funding provided by the local government or supported by some initiative as it was in 2012.

\section{Analysis of the Research Results}

The research results show that institutionalized and informal way of organizing intergenerational cultural programs is overlapping with each other. The main findings are that in participating intergenerational cultural programs for older people in LTCIs are both professional and amateur artists. Initiative in participating and organizing intergenerational cultural programs come from 
both cultural event managers of LTCIs and volunteers, for example, church communities, student organizations and other amateur collectives in fine arts. The cultural programs are aligned with the artists and authorities of the LTCIs in advance. There is no single model for all three types of LTCIs how to organize intergenerational cultural programs. The main goal of these cultural programs is to achieve active and healthy ageing in LTCIs.

Further, the results of the study will be analyzed. There will be clarified answers to the main semi-structured questions and identified major issues with organizing intergenerational cultural programs. Analysis will be structured into five sections that are made according to research questions: (1) Spatial layout of the place for intergenerational cultural programs to be held; (2) Initiative to organize intergenerational cultural programs in LTCIs; (3) Participants of intergenerational cultural programs in LTCIs; (4) Participants of intergenerational cultural programs in LTCIs; and (5) How the intergenerational cultural programs are happening?

Spatial Layout of the Place for Intergenerational Cultural Programs to Be Held

Spatial layout differs between LTCIs. If LTCIs were built when Latvia was part of the Soviet Union, then for concerts and other cultural events there is a special auditorium for bigger events and several rooms for workshops. Auditoriums are designed very similarly to those concert halls, what is very common in most of the small towns in Latvia (Figure 1). All of them have a stage for artists and seats are placed in rows where the audience (in this case older people of LTCIs) can have their seat. Most of the auditoriums have at least one piano or keyboard. One of the tasks for cultural event managers is to keep an instrument in good shape. Keeping an instrument in good shape often depends on the financial availability of LTCIs. It is an extra expense for LTCIs to maintain the instrument, for example, piano tuning. That explains why not always instruments in LTCIs are in good condition. Some of these institutions were also equipped with sound equipment, too. 
Figure 1 Spatial Layout of the Place for the Intergenerational Cultural Program in State LTCI "Krasti." Artists Are Presenting the Musical Program and Communicating with Older People by Sharing Stories to Each Other

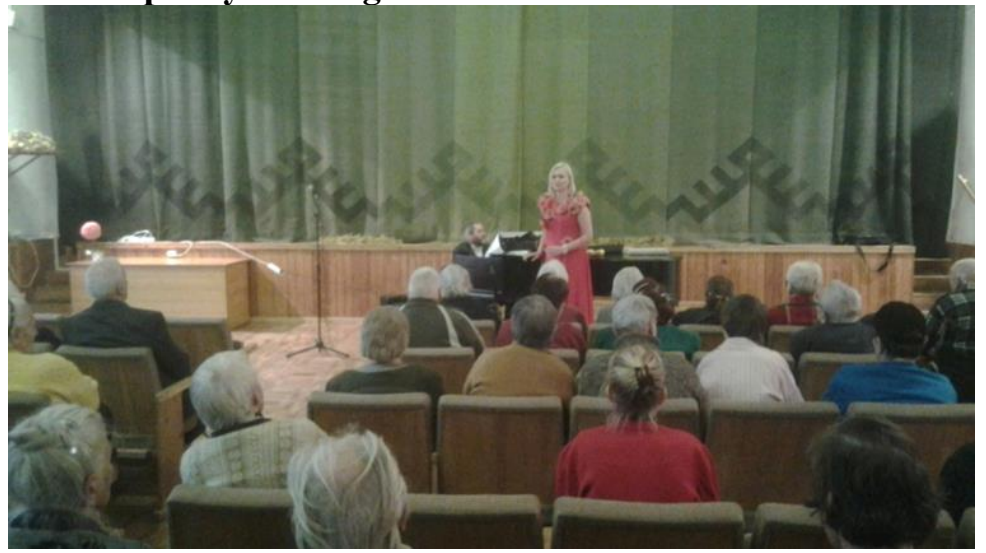

Source: Authors' archive.

It is more problematic to find the appropriate space for events in private LTCIs. Those two private LTCIs that were visited had a different spatial layout for an intergenerational cultural event. LTCI "Upe" previously was a hospital and owner of this institution had chosen a big operation room as a facility for cultural programs (Figure 2). This institution does not have even a piano, so artists have to bring their own instrument. In addition, this room does not have a stage that would classically divide artist's space from the audience. Older people are sitting very cramped in this former operation room (Figure 3), and it is not ventilated, so during an event gets very hot in there. Another private LTCI "Vilnis" previously was a hotel. It also does not have a special place for cultural programs. Usually, an hour-long intergenerational cultural program been held at lunchtime, and the facility that is used for that is the dining room of the LTCI. Very disturbing is that during the event one can hear on a kitchen staff preparing lunch. According to the theory of institutional ecology, the insufficiency of resources such as restricted space and 
organizational abilities are limiting the quality of intergenerational cultural programs in LTCIs.

Figure 2 Spatial Layout of the Place for the Intergenerational Cultural Program in Private LTCI "Upe." Students from Several Student Organizations Are Visiting LTCI and Performing for Older Adults as Part of the Intergenerational Program

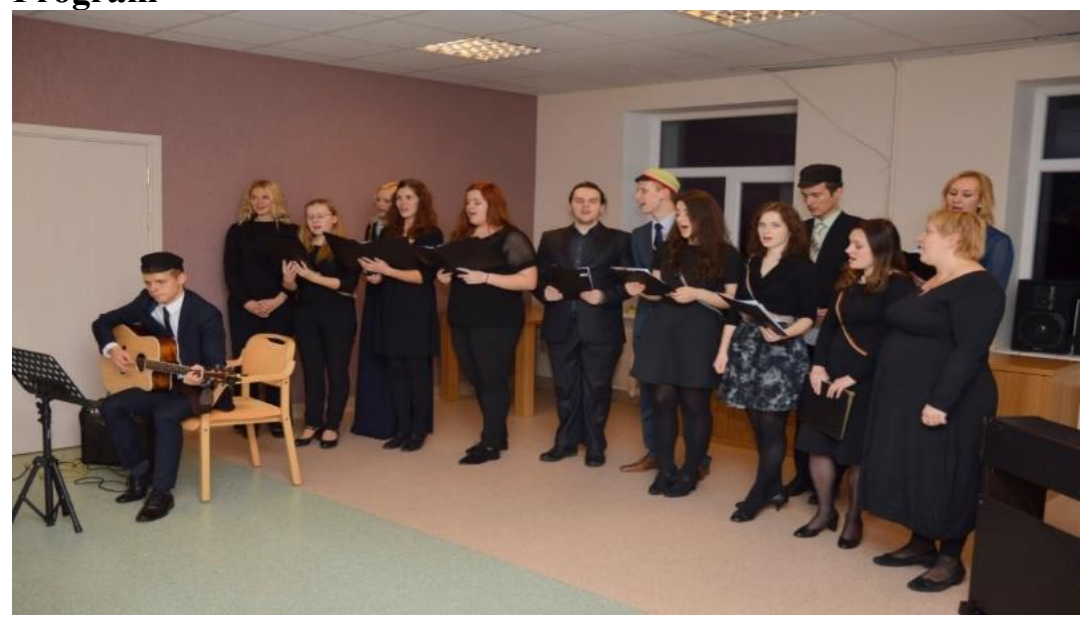

Source: Authors' archive.

Initiative to Organize Intergenerational Cultural Programs in LTCIS

Initiative to organize intergenerational cultural programs primarily based on self-initiative of the cultural event managers in the state and the local government LTCIs and on owners of the institution in the private LTCIs. In both cases, cultural event managers or owners of LTCIs use their personal contacts to persuade artists to perform in LTCIs. The cultural event managers are positively acknowledging active involvement in intergenerational cultural programs provided by churches, schools, student organizations, various amateur collectives, and interest clubs. The most active time of the year when many people from the community are interested in performing in LTCIs is Christmas time. During the Christmas time, the cultural life in LTCIs is at its 
peak. However, after that, the cultural event managers admit that in order to continue with the same pace of the activities in LTCIs initiative first must come from the cultural event managers themselves. It is seldom when the initiative to perform in LTCIs comes from the professional artists first. The cultural event managers also point out that there is no financial support available for these cultural programs. The artists' participation in intergenerational cultural programs for older people in LTCIs is based on volunteering.

Figure 3 Spatial Layout of the Place for the Intergenerational Cultural Program in Private LTCI “Upe.” Older Adults Are Participating in the Intergenerational Program

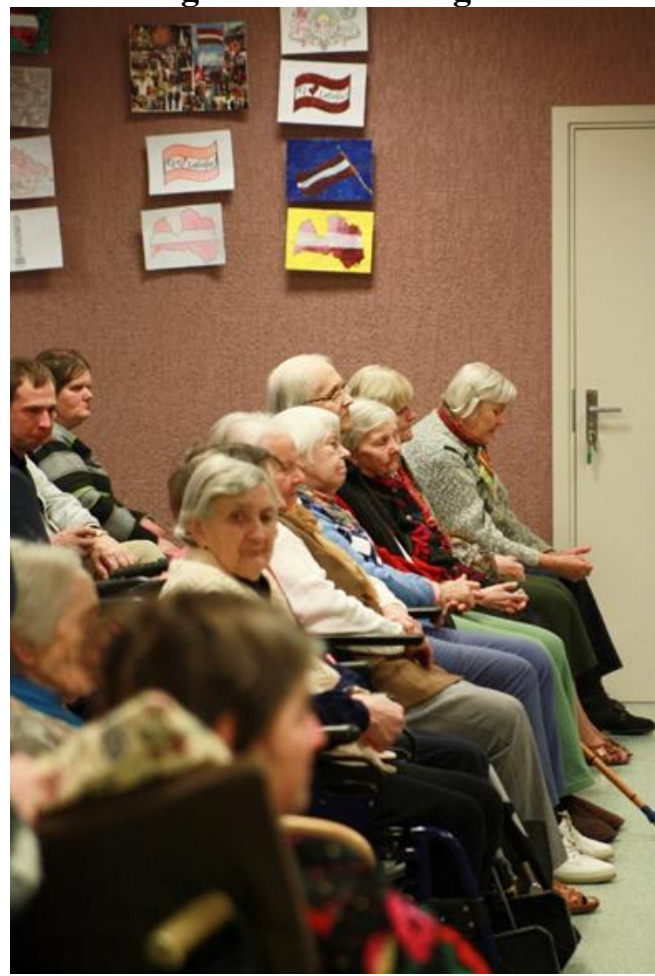

Source: Authors' archive.

The Way to Organize Intergenerational Cultural Programs for Older Adults in LTCIs 
Intergenerational cultural programs in each of LTCIs very much depend on various aspects such as enthusiasm of competent staff or cultural event manager, active participation of older adults, financial availability to carry out these cultural programs, community, and local government support, and voluntary participation. The cultural event manager of LTCI "Krasti" remembers that in the EY2012 there were many different cultural activities in LTCIs in Latvia. The main reason for such an active participation of community and interest of various artists to participate in intergenerational cultural programs was the financial grants for various projects to promote active ageing and intergenerational solidarity in LTCIs. That year LTCIs and local governments were able to get funding for various artists for example musicians, actors, and painters and pay them for their work at LTCIs. Four years later when these interviews were done, cultural event managers pointed out that the situation is dramatically changed. As it is already analyzed in the previous section of this study that there is not provided additional funding for cultural events in LTCIs. It means that since the year of 2012 most of these activities that started in 2012 discontinued, and currently these intergenerational cultural programs depend on the personal enthusiasm of cultural event managers in LTCIs and voluntary nature of each community member.

Another important issue the cultural event managers pointed out that older people who are reaching a certain age are losing interest to participate in intergenerational cultural programs. The cultural event managers are persuading and motivating them to take part in the intergenerational cultural programs. The cultural event managers of LTCIs are regularly reminding to older people long before coming up a new event or activity in LTCIs. Preparing for an artist to visit LTCIs and give a performance, cultural event manager prepares posters with information about the event that is coming up and every day for a whole week is making an announcement over the internal radio.

Very often, some of older adults are not able to participate in an event or activity because they have dementia or disability. Those with severe dementia condition need personal assistance in order to attend an event. In the state LTCIs, there is a shortage of 
staff members in order to assist each of residents who are in need that is why some older persons have to stay in their rooms. The slightly different situation is in private LTCIs. There are lesser older persons, and staff can pay better attention to each older adult (but not in all cases, private not always mean better). Some private LTCIs are doing a better job by attracting young people who are temporally working in LTCIs as volunteers. Older people with some physical disability are also deprived of attending an event or participating in some activity because of a shortage of wheelchairs and some other helping aids for them to be mobile.

The cultural program an artist prepares himself or herself in advance and discusses it with the cultural event manager before the event. The length of the intergenerational program is important, too. Usually, it must not be longer than an hour because it is difficult for older people to concentrate their attention for a longer period. The timing of activities is just as important as the length of the intergenerational cultural program. Mostly the cultural event managers preferring the time for an activity before older people will have lunch. It is important that the activities are not overlapping in the same LTCI.

Participants of Intergenerational Cultural Programs in LTCIs Participants of intergenerational cultural programs in LTCIs are very different. Main participants are older people residing in LTCIs, but those who are visiting LTCIs during the cultural programs can vary from an amateur artist to a very professional. The age differences between older adults and artists are not always the same. For example, when children from school or student organizations are visiting LTCIs then we can talk about meeting young and old generations. During their visits, young people are singing and playing music. The music they are playing most of the time is a popular music what young people on that age are listening. This is a good opportunity for older people to get to know perhaps the new music genres. Some professional artists are invited who are the same age as some of older residents of LTCIs. Usually, they are some actors or former singers who are famous still acting in TV plays or singing in concerts that are broadcasted on the television. These artists are not only contributing to the 
intergenerational cultural programs, but they are a very good example to others for active ageing, too.

Some professional artists are limited to give an outstanding professional performance because very often accompanists are refusing to perform free of charge. In this case, sometimes the cultural event managers are looking for a donation from a local store next door or paying a little amount of money from their own pocket. One example was mentioned when an artist was performing in LTCIs and paying himself or herself to the accompanist.

\section{How Are the Intergenerational Cultural Programs Happening?}

In all LTCIs which authors visited intergenerational cultural programs took place before lunch. The cultural event managers explained that in the first half of the day, older people have more energy and they can better concentrate than after lunch. From an artist is required prepared scenario of the coming up event. For example, if they are musical performances then artists are required to send a list of songs beforehand and to prepare a storyline or socalled scenario with text between songs in order to make it less formal that way is avoiding usual concert format and making it more interesting for older adults. The performance must not exceed one hour in length. In order for an intergenerational interaction to happen, an artist will have to make a dialogue with older people of LTCIs. At least half an hour before the event, older adults are starting to take seats in the auditorium. The introduction before the event is necessary. Usually, the cultural event manager or another person in charge (it also can be an active older person who has become an authority in LTCIs) introduces with an artist and tells a little bit about him. The rest cultural event manager leaves for an artist himself or herself to tell. Generally, older people are very curious about artists' personal life, and the artist must be prepared to answer to all kinds of unexpected questions. The artist must be prepared that some older people in the auditorium have dementia and not all of them can sit still for an hour. They might walk around and make comments while the artist is performing. When performance is finished, some of older 
people are willing to talk a little bit more with an artist and a lot of them, want to take pictures with the performer.

\section{Discussion}

The aim of the study is to find out the ways, how intergenerational cultural programs of professional and amateur activities implement in LTCIs. Older people in LTCIs are population group that has to be involved in active ageing policy implementation processes. The important issue is how to provide regularity of the intergenerational cultural programs for older people living in LTCIs. The study shows that it mostly depends on the initiative of the event managers of LTCIs. It also depends on the interest of both older people and the professional or amateur artists to participate in the intergenerational cultural programs in LTCIs.

Normative acts, instructions, regulations on LTCIs do not foresee that the cultural programs as such are a necessity for older people living in LTCIs. The regulations do not state that the intergenerational cultural programs must be regular for older people in LTCIs. The focus of long-term care for older people is to be able to provide for them basic needs. Authors believe that older people who stay in LTCIs also deserve some quality of life more than just satisfying their basic needs (room and board). Older people must have some activities and some "food for soul" in order to have that. The intergenerational cultural programs can be one of the ways, how to improve living conditions for older people in LTCIs.

In the literature review authors welcoming, that the importance of the intergenerational solidarity and the intergenerational cultural programs is acknowledged. For example, there is an emphasis on the importance of the interaction and the meaning of the solidarity between generations; there is an emphasis on the necessity to increase cooperation, interaction, or exchange between any of two generations. Although the fact how important it is to older people who live in LTCIs to have these intergenerational cultural programs is not explored and authors could not find offered solutions on how to achieve the intergenerational solidarity and how to implement 
intergenerational cultural programs, and to make them regular for older people in LTCIs.

Authors in this study want specifically to point out the importance of intergenerational cultural programs for older people in LTCIs. These programs for older people are necessary just as much as their basic needs in order to avoid daily routine, suffering from boredom, and preventing them from feeling abandoned in LTCIs.

From the perspective of the theory of institutional ecology, study shows that the spatial layout where intergenerational cultural programs will take place is very important, too. The paradox is that older people not always got their basic needs to the best quality and some things were even lacking in LTCIs during the Soviet Union, but at the same time in all LTCIs had the special auditorium for the cultural programs. Study proves that in LTCIs built during the Soviet Union, they all had an auditorium for the cultural programs. The auditoriums are missing in those LTCIs' buildings, what previously was something else, for example, a hospital or a hotel.

Authors think that some elements of the social time experience are respectful in organizing LTCIs. The suggestion is for the architects to consider the specific setup of LTCIs when they plan to build new LTCIs.

The intergenerational cultural programs are a necessity for every human being, regardless of his or her age. Another aspect that the intergenerational cultural programs importance for older people in LTCIs is underestimated for the reason that it brings the new changes in daily routine in lives of older people in LTCIs. Living in LTCIs older people are living in restricted conditions both environment and society. However, from a medical perspective, there are authors who are writing about the importance of change for those who live in restricted settings. The option that these changes can achieve with cultural programs, and particularly in LTCIs settings it would be well achieved with intergenerational cultural programs is not a common opinion that would be encouraging further discussion and motivating to take some further action. The active ageing policy foresees various 
activities for older people, including for those who reside in LTCIs. The study shows that LTCIs only partly follow this policy.

Every individual is in need for the cultural programs and interaction with different people for legitimate reasons. The study shows that the cooperation between generations not regulated in LTCIs. The security of older people is the most important in LTCIs, but the locked door of the LTCIs do not encourage interaction between generations and implementation of the active ageing policy. Authors associate the setting of LTCIs to fit to the style of the total institution. This institutionalized setting does not encourage intergenerational solidarity and realization of intergenerational cultural programs for older people.

Currently, people who are organizing intergenerational cultural programs are participating voluntary. There is not defined demand for cultural event manager and for a social worker to have competence in the event organizing. People who are organizing cultural events in LTCIs selected for this job position randomly. LTCIs do not have any criteria on what previous experience must one have in order to fit to the position being a cultural event organizer in LTCIs.

The study shows that after EY2012 there are limited possibilities to follow active ageing policy in LTCIs. The national and the local authorities should take measures to encourage and support citizen-based initiatives and volunteering activities, including those involving in the intergenerational cultural programs. Cooperation between communities and the sharing of best practices and experiences could promote by local governments, LTCIs and other organizations (such as NGOs, churches, schools, and student organizations) who are involved in these programs. The implementers of public policy should support intergenerational cultural programs by promoting community engagement and encouraging volunteering. It is very important that the intergenerational cultural programs comprehend various groups of older people including those who reside in LTCIs. It is obvious that there is a deficiency of intergenerational solidarity programs between younger and older people, including cultural programs, in LTCIs and that is why there is a necessity to research the topics concerning these programs. 


\section{Conclusion}

The implementation of intergenerational cultural programs depends on specific management, staff position, spatial layout, financial availability, and free will and enthusiasm of all participants.

The WHO defines "active ageing as a process of optimizing opportunities for health, participation, and security in order to enhance the quality of life as people age. It needs to be applied to older people, LTCIs residents as a special group." Intergenerational cultural programs are one of the ways, how to involve them in active ageing processes.

The following conclusions can be drawn based on document analysis concerning intergenerational cultural programs for older people in LTCIs and results conducted from semi-structured interviews done with LTCIs" cultural event managers and artists who participated in these events or activities.

Interviews with the cultural event managers confirm that there would be a need for intergenerational cultural programs in LTCIs on a regular basis. The cultural event managers' enthusiasm and voluntarily by artists does not provide this regularity of these events or activities for older people.

From the perspective of the theory of institutional ecology, intergenerational cultural programs can happen in those LTCIs facilities where the spatial layout of institution foresees a special auditorium for events to be held. Another crucial aspect that makes intergenerational cultural programs available for all older people to sufficient amount of staff members in LTCIs because some older people need assistance in order to take part in the event or activity. Shortage of helping aids also is limiting equal accessibility to intergenerational cultural programs for all older adults- LTCIs' residents.

The study shows that older people who are living in LTCIs settings are subject to everyday routine. LTCIs care provision is very much dependent on the authorities of the particular institution. The lack of interaction between older adults and the more active part of society prevents the finding of effective ways of achieving that the care in LTCIs is in accordance with the active ageing policy. 
According to the study results, the intergenerational cultural programs are mainly based on the initiative coming from volunteers and the enthusiasm of the event managers in LTCIs, and it shows that there are many unsolved issues within the institution in promoting intergenerational solidarity and organizing cultural programs. Finding a right solution to these issues is neither the social careers nor medical staff competency.

\section{Recommendations}

The study shows that it is important for an event manager to have a cultural capital and an experience in organizing events for older people residing in LTCIs. LTCIs management has limited resources to accommodate professional artists. It is one of the reasons, why a person appointed to manage cultural life in LTCIs has to have a cultural capital and personal contacts in a world of art. On the other hand, amateurs including various senior collectives, children from school, and students are very much willing to participate in intergenerational cultural programs in LTCIs because they are using it as a platform for an exposure and as an opportunity to perform in front of an auditorium. Volunteers are one of the ways, how some LTCIs are finding a solution to solve the problem of shortage of staff members.

Even though the amateurs give their performance free of charge in LTCIs, most of the times they require to accommodate them with transport for them to get to LTCIs. Transport availability in each of LTCIs differs because of the financial situation in each of LTCI. It is very different from all three kinds of LTCIs (state, local government and private). Better cooperation between state, local government, and private LTCIs could contribute to solving transportation problems. Authors suggest that specifically trained social workers equipped with additional resources would be suitable to take on to duties concerning intergenerational cultural programs including the organizing the transport for the participants.

In order to implement intergenerational cultural programs successfully in LTCIs, there are two ways of doing that. Firstly, state, and local government must include intergenerational cultural programs in their annual financial planning. Secondly, one could 
establish the special foundation for intergenerational cultural programs based on the contributions of public and private organizations, and private donations.

Concerning spatial layout for intergenerational cultural programs, not all LTCIs have suitable auditoriums for them to be held. As a solution for those LTCIs whose facilities are small for having older people to participate all at once in one room, the solution could be found by dividing them into smaller groups that can fit in one room and organize them cultural programs in a group setting. Another alternative for those LTCIs without any extra facility apart from rooms of their older residents, intergenerational cultural programs could be a seasonal solution as outdoor events organized in a back yard of LTCI.

\section{Acknowledgements}

This research has been generously supported by:

1. The SIforAGE project. SIforAGE consortium: Providing innovative solutions for an active and healthy ageing. Seventh Framework Program. European Commission. Link to the website: www.siforage.eu

2. The University of Latvia and The Advanced Social and Political Research Institute (ASPRI) was one of the partners in this research and were one of the 20 partners participating in this project. Link to the website: http://szf.lu.lv/eng/petnieciba/sppi-instituts/

3. The National Research Program SUSTINNO. Project No.2. Social Dimension of Sustainability and Social Innovation. Link to the website: https://dspace.lu.lv/dspace/handle/7/31767

\section{References}

Abrutyn, S. (2012). Toward A Theory of Institutional Ecology: The Dynamics of Macro Structural Space. Review of European Studies, 4(5), 167-180.

AGE Platform Europe. (2010). Intergenerational Solidarity the Way Forward: Proposals from the NGO Coalition for a 2012 European Year for Active Ageing and Intergenerational Solidarity. Retrieved from www.age- 
platform.eu/images/stories/EN/CoverAGE/EN/21879_brochure_ age_2010_en.pdf

Akkerman, S. F., \& Bakker, A. (2011). Boundary Crossing and

Boundary Objects. Review of Educational Research, 81(2), 132169.

Alders, P., Comijs, H. C., \& Deeg, D. J. H. (2016). Changes in Admission to Long-Term Care Institutions in the Netherlands:

Comparing Two Cohorts Over the Period 1996-1999 and 20062009. European Journal of Ageing, 9(2), 1-9.

Amparo Cruz-Saco, M. (2010). Intergenerational Solidarity. In M. A.

Cruz Saco \& S. B. Zelenev (Eds.), Intergenerational Solidarity.

Strengthening Economic and Social Ties (1st ed., pp. 9-34).

New York, NY: Palgrave Macmillan.

BC Care Providers Association. (2009). Creating Caring

Communities: A Guide to Establishing Intergenerational

Programs for Schools, Care Facilities and Community Groups.

Retrieved from www.bccare.ca/wp-content/uploads/BCCPA-

Intergenerational-Toolkit.pdf

Bengtson, V. L. (1993). Is the "Contract Across Generations"

Changing? Effects of Population Aging on Obligations and

Expectations Across Age Groups. In V. L. Bengtson \& W. A.

Achenbaum (Eds.), The Changing Contract Across Generations (pp. 3-24). New York, NY: A. de Gruyter.

Bengtson, V. L., \& Oyama, P. S. (2007). Intergenerational Solidarity:

Strengthening Economic and Social Ties: Background Paper.

Retrieved from

www.un.org/esa/socdev/unyin/documents/egm_unhq_oct07_ben gtson.pdf

Bērziņš, A. (2015). Sociālo pakalpojumu pieejamības un attīstības tendences Latvijā [Tendencies to access and development of social services in Latvia] [PowerPoint slides from conference]

"Aprūpe mājās Latvijā - pieejamība, attīstība, izaicinājumi" (Home Care in Latvia-Accessibility, Development,

Challenges). Retrieved from www.samariesi.lv

Central Statistical Bureau of Latvia (CSB). (2015). Recipients of

Pensions and State Social Maintenance Benefit at the End of the

Year: Social Security: Key Indicators. Retrieved from

www.csb.gov.lv/en/statistikas-temas/social-security-key-

indicators-30686.html 
Central Statistical Bureau of Latvia (CSB). (2016). Resident

Population by Major Age Group at the Beginning of the Year.

Retrieved from

http://data.csb.gov.lv/pxweb/en/Sociala/Sociala_ikgad_iedz_ iedzskaits/?tablelist=true \&rxid=a79839fe-11ba-4ecd-8cc3$4035692 \mathrm{c} 5 \mathrm{fc} 8$

Cohen, G. D., Perlstein, S., Chapline, J., Kelly, J., Firth, K. M., \& Simmens, S. (2006). The Impact of Professionally Conducted Cultural Programs on the Physical Health Mental Health, and Social Functioning of Older Adults. The Gerontologist, 6(46), 726-734.

Cohen, S. S. (2007). 50 Essays: A Portable Anthology. Boston: Bedford/St. Martin's.

Davidson S. R., \& Boals-Gilbert, B. (2010). What Age Gap? Building Intergenerational Relationships. Dimensions of Early Childhood, 2(38), 23-29.

European Commission. (2015a). Employment, Social Affairs \& Inclusion Eurostat Demography Report. Retrieved from http://ec.europa.eu/eurostat/documents/3217494/6917833/KEBM-15-003-EN-N.pdf/76dac490-9176-47bc-80d9-

029e1d967af6

European Commission. (2015b). The 2015 Ageing Report: Economic and Budgetary Projections for the 28 EU Member States (20132060). Retrieved from

http://ec.europa.eu/economy_finance/publications/european_eco nomy/2015/pdf/ee3_en.pdf

Featherstone, H. (2014). Cultural Participation by Older People: Are We Aging Older in Life? Retrieved from

www.longlivearts.eu/upload/files/Helen\%20Featherstone.pdf

For the Wellbeing and Dignity of Older People (WeDO). (2012).

European Quality framework for long-term care services. WeDO project 2010-2012. Retrieved from www.nhi.ie/doc.php?id=924

Generations United. (2006). Intergenerational Shared Sites:

Troubleshooting. Retrieved from

https://s3.amazonaws.com/pushbullet-uploads/ujzNDwQrsR2-

YYu8NQ8Cm2oNnfF30IdiOGIoMrzI6vxd/06-SharedSites-

Report-Troubleshooting.pdf

Generations United. (2007). The Benefits of Intergenerational

Programs. Retrieved from 
www.gu.org/LinkClick.aspx?fileticket=71wHEwUd0KA\%3D\&t abid $=157 \&$ mid $=6$

Kaplan, M., \& Sanchez, M. (2014). Intergenerational Programs and Policies in Ageing Societies. In S. Harper \& K. Hamblin (Eds.), International Handbook on Ageing and Public Policies (pp. 367-383). Cheltenham, UK, Northampton, MA: Edward Elgar Publishing.

Klimczuk, A. (2015). Economic Foundations for Creative Ageing Policy: Volume I: Context and Considerations. New York, NY: Palgrave Macmillan.

Latvijas Republikas Labklājības Ministrija (Welfare Ministry of Latvia). (2011). Eiropas gads aktīvai novecošanai un paaudžu solidaritātei [European Year for Active Ageing and Solidarity Between Generations]. Retrieved from www.lm.gov.lv/upload/eg2012/eg2012_progr_fin.pdf

Latvijas Republikas Labklājības Ministrija (Welfare Ministry of Latvia). (2013). Sociālās aprūpes pakalpojumu ilgtspēju nodrošinās to balstīšana sabiedrībā [LM: Social care services will ensure the sustainability of public reliance]. Retrieved from www.lm.gov.lv/news/id/4786

Lloyd, L., Tanner, D., Milne, A., Ray, M., Richards, S., Sullivan, M. P.,... Phillips, J. (2014). Look After Yourself: Active Ageing, Individual Responsibility and the Decline of Social Work with Older People in the UK. European Journal of Social Work, 17(3), 322-335.

Macionis, J. J., \& Plummer, K. (2008). Age Stratification, Children and Later Life. In J. J. Macionis \& K. Plummer (Eds.), Sociology: A Global Introduction (4th ed.) (pp. 402-427). Edinburgh Gate, UK: Pearson Education Limited. Mather, M. (2007). The New Generation Gap. Washington, DC: Population Reference Bureau. Retrieved from www.prb.org/Publications/Articles/2007/NewGenerationGap.as $\mathrm{px}$

Miller, B. K. (2002). Theories of Aging. In C. B. Lewis (Ed.), Aging. The Health-Care Challenge: An Interdisciplinary Approach to Assessment and Rehabilitative Management of the Elderly (4th ed., pp. 3-10). Philadelphia: F.A. Davis Co.

Newman, S., \& Hatton-Yeo, A. (2008). Intergenerational Learning and the Contributions of Older People. Ageing Horizons. (8), 
31-39. Retrieved from

http://riolis.ipleiria.pt/files/2011/03/Intergenerational-Learningand-the-Contributions-of-Older-People.pdf

OECD. (2011). OECD Ministerial Meeting on Social Policy. Session

3. Paying for the Past, Providing for the Future:

Intergenerational Solidarity. Retrieved from

www.oecd.org/els/public-pensions/47711990.pdf

OECD. (2016). OECD Data. Elderly Population. Retrieved from https://data.oecd.org/pop/elderly-population.htm

Oliver, D., Foot, C., \& Humphries, R. (2014). Making Our Health and Care Systems for an Ageing Population. London, UK: The King's Fund. Retrieved from

www.kingsfund.org.uk/sites/files/kf/field/field_publication_file/ making-health-care-systems-fit-ageing-population-oliver-foothumphries-mar14.pdf

Österle, A., \& Rothgang, H. (2010). Long-Term Care: Long-Term

Care and the Welfare State. In F. G. Castles, S. Leibfried, J. Lewis, H. Obinger, \& C. Pierson (Eds.), The Oxford Handbook of the Welfare State (pp. 378-405). Oxford: Oxford University Press.

Parliament of the Republic of Latvia (Latvijas Republikas Saeima). (2002). Sociālo pakalpojumu un sociālās palīdzības likums [Law on social services and social assistance]. Retrieved from https://likumi.lv/doc.php?id=68488

Parliament of the Republic of Latvia (Latvijas Republikas Saeima). (2010). Apvienotās Nāciju Organizācijas Konvencijas "Par personu ar invaliditāti tiesībām" ratifikācijas īstenošanas gaita [Ratification of United Nations Convention on the Rights of Persons with Disabilities]. Retrieved from www.saeima.lv/en Piszczek, M. M., \& Berg, P. (2014). Expanding the Boundaries of Boundary Theory: Regulative Institutions and Work-family Role Management. Human Relations, 67(12), 1491-1512.

Republic of Slovenia Ministry of Labour, Family and Social Affairs.

(2010). The Strategy of Care for the Elderly till 2010 -

Solidarity, Good Intergenerational Relations and Quality Ageing of the Population. Retrieved from www.mddsz.gov.si/fileadmin/mddsz.gov.si/pageuploads/dokum enti_pdf/strategija-_EN-starejsi.pdf 
Rezgale-Straidoma, E., \& Rasnača, L. (2015). Risks While

Deinstitutionalizing Long-Term Elderly Care: The Case of

Latvia. Socialiniai Tyrimai. (2), 82-92.

Rezgale-Straidoma, E., \& Rasnača, L. (2016). Long-Term Elderly

Care Quality Assurance Challenges for Local Governments.

Research for Rural Development. (2), 203-209. Retrieved from

http://llufb.llu.lv/conference/Research-for-Rural-

Development/2016/LatviaResRuralDev_22nd_vol2-203-209.pdf

Rollins, J. (2013). Bringing the Arts to Life. A Guide to the Arts and

Long-Term Care. Retrieved from

www.recreationtherapy.com/articles/BringingArtToLife.pdf

The World Bank. (2015). The Active Ageing: Challenge for Longer

Working Lives in Latvia. Retrieved from

http://pubdocs.worldbank.org/pubdocs/publicdoc/2015/9/205791

443642635843/WB-Latvia-Active-Aging-Report.pdf

Toepoe, V. (2011). Cultural Participation of Older Adults:

Investigating the Contribution of Lowbrow and Highbrow

Activities to Social Integration and Satisfaction with Life.

International Journal on Disability and Human Development, 2(10), 123-129. Retrieved from

www.lissdata.nl/dataarchive/hosted_files/download/1072Cached

Tymowski, J. (2015). European Year for Active Ageing and

Solidarity between Generations (2012) European

Implementation Assessment: European Parliamentary Research

Service. Retrieved from

www.europarl.europa.eu/RegData/etudes/IDAN/2015/536344/E

PRS_IDA(2015)536344_EN.pdf

United Nations. (2006). Convention on the Rights of Persons with

Disabilities. Geneva. Retrieved from

www.un.org/esa/socdev/enable/rights/convtexte.htm

World Health Organization (WHO). (2002). Active Ageing: A Policy

Framework. Geneva. Retrieved from

http://apps.who.int/iris/bitstream/10665/67215/1/WHO_NMH_

NPH_02.8.pdf

World Health Organization (WHO). (2011). Global Health and

Ageing. Retrieved from

www.who.int/ageing/publications/global_health/en/

World Health Organization (WHO). (2016). Global Strategy and

Action Plan on Ageing and Health (2016-2020): A Framework 
for Coordinated Global Action by the World Health Organization, Member States, and Partners Across the Sustainable Development Goals. Retrieved from http://who.int/ageing/GSAP-Summary-EN.pdf?ua=1 